\title{
Theorising International Postgraduate Student Lecturers' Experiences in South Africa
}

\author{
Noluthando Matola ${ }^{1}$, Kehdinga George Fomunyam ${ }^{2, *}$ \\ ${ }^{1}$ Post Graduate Research and Support, Office of the Deputy Vice Chancellor, Durban University of Technology, South Africa \\ ${ }^{2}$ Faculty of Management Sciences, International Center of Non-Violence, Durban University of Technology, South Africa
}

Received May 31, 2020; Revised September 9, 2020; Accepted November 1, 2020

\begin{abstract}
Cite This Paper in the following Citation Styles
(a): [1] Noluthando Matola, Kehdinga George Fomunyam , "Theorising International Postgraduate Student Lecturers' Experiences in South Africa," Universal Journal of Educational Research, Vol. 9, No. 6, pp. 1274-1283, 2021. DOI: 10.13189/ujer.2021.090616.
\end{abstract}

(b): Noluthando Matola, Kehdinga George Fomunyam (2021). Theorising International Postgraduate Student Lecturers' Experiences in South Africa. Universal Journal of Educational Research, 9(6), 1274-1283. DOI: 10.13189/ujer.2021.090616.

Copyright $@ 2021$ by authors, all rights reserved. Authors agree that this article remains permanently open access under the terms of the Creative Commons Attribution License 4.0 International License

\begin{abstract}
The internationalisation and globalisation of our current world has led to the mobility of students across borders in the pursuit of quality education. South Africa has become a popular choice destination for some of these students who intend to further their studies by undertaking postgraduate programs in different fields. For variety of reasons, these students take up part time jobs whilst studying, and some continue to tow the education line by becoming part time lecturers. This paper explores the experiences of postgraduate student lecturers in South Africa. Using a qualitative case study research approach, this paper adopts a purposeful sampling strategy to generate data from participants who were pursuing their postgraduate degrees at masters and $\mathrm{PhD}$ levels. Findings reveal that the major challenges faced by postgraduate student lecturers in South Africa include culture shock, technological barrier, inadequate academic resources to work with, and the struggle to create a study-work-life balance. This paper recommends that international postgraduate students lecturing be trained and taught the basics of some South African cultures before they are allowed to handle students in the classroom. The learning environment should be made conducive enough to facilitate effective teaching and learning because, overcrowded classrooms affect both lecturers and students. Lastly, these student lecturers should be offered training in the use of technologies used for delivering their lectures, and all learning resources needed to ensure a seamless teaching and learning process should be made available.
\end{abstract}

Keywords Postgraduate, International Students, Lecturer, South Africa, Learning, Education

\section{Introduction}

In recent years, the mobility of students across borders in the pursuit of education has become a common phenomenon. This is due to the demand for internationalisation and globalisation of our world, resulting in the inflow of international students into countries which host internationally recognised institutions. Student outflow from Africa to other continents around the world has tremendously increased, such that as at 2014, African students comprised $24 \%$ of all internationally mobile students around the world. Choice destinations for these international students include USA, UK, France and Europe with a recent diversion to Asian and Arab nations (Schulmann, 2017). According to UNESCO (2009), an international student is a student who leaves his/her country of origin, and moves to another country to study. This is a student who obtains the entry qualification to study in another country, is not a permanent resident of this country, and moves to this new country with the sole purpose of studying (OECD, 2008; UNESCO, 2009).

Recent analysis reveals that some African students are choosing to stay within Africa, with South Africa as the choice destination (ICEF monitor, 2017). In fact, South 
Africa ranks second as the choice destination for international mobile students from Africa according to TAE (2019). This preference by international students is influenced by factors such as the proximity of South Africa to their home countries, affordability, and the quality and reputation of its institutions of higher learning (ICEF monitor, 2017). South Africa recorded the admission of about 74,000 international students in 2013, and $15 \%$ of these students were pursuing postgraduate studies (ICEF Monitor, 2013). A postgraduate course or research refers to a form of study offered by an institution of advanced learning. Postgraduate programs are conduits through which universities develop research capacity and also generate high skills needed for a functional economy. It takes various forms but a post graduate student is a student considered to have completed a bachelor's degree or a diploma. The requirement for admission into these programmes varies from institution to institution, and is generally viewed as an apprenticeship into mastering systematic research processes (Mutala, 2011).

Most of these postgraduate students in South Africa become directly or indirectly involved in the teaching and learning at their institutions of learning as student lecturers. These research students with several years of professional experience and complete commitment to study begin to teach other students, individually or in groups. Their dedication to education makes the transition from being a student to a lecturer while still studying easier. Notwithstanding, during the course of their studies, and roles as lecturers, international postgraduate students in South Africa garner a multitude of experiences. This paper therefore aims to explore the experiences of these students, using a university in KwaZulu-Natal as an example. This study provides new insights into the experiences and challenges faced by international postgraduate student lecturers in South Africa, and the value of adopting several measures to ensure a seamless teaching and learning process. These experiences will not only expose the implications of lecturing on the student, but would provide more insight on how to improve their efficiency.

\section{The Art of Lecturing: A Literature Review}

The goal of every lecturer is for a student to learn during the lectures, promoting learning can take place during later activities, such as reading lecture notes or engaging in exercises. If lecturers are to succeed in ensuring learning during lecture time, then they need to engage processes that enhance durable encoding of facts, concepts and ideas that are covered during the lecture. DeWinstanley and Bjork (2002) argue that learning does not take place by a mere recording process but rather an interpretative process where new information is linked to information that already exists, to make meaning. It is therefore vital for different enactments of this to be explored so as to enhance the meaning of the term.

Drawing from these discussions, several scholars such as Kember (1997), Young (2002), Knight and Wood (2005) and Cotton, Warren, Maiboroda and Bailey (2007) have suggested four concepts that can be engaged as part of the lecturing process for it to be effective; these key concepts are intention, transmission, receipt of information and output. Intention, as the first basic concept, avers that when lecturing, the lecturer's intention may be considered to be delivering a topic as per the syllabus requirements, to generate understanding and to stimulate interest. For a lecture to be considered successful, it must generate understanding. This means the lecturer should be able to explain key concepts relating to the subject matter. According to Atkins and Brown (2002) one is able to clearly explain a subject if they have precise knowledge of it. Therefore in preparing for the lecture, the lecturer is expected to have in-depth knowledge of the topic and also take into consideration the prior knowledge of learners. When lecturing, the lecturer also intends to stimulate interest to catch the attention of the students.

The second basic concept, transmission, argues that a lecturer sends a message verbally, extra verbally and nonverbally to the students. The verbal messages may be communicated through a definition of terms, explaining concepts or providing examples for emphasis. The 'extra verbal' component constitutes the lecturer's vocal qualities, hesitations, errors and use of pauses and silence. The 'nonverbal' component includes the lecturer's gestures, and facial expressions and the student may consider all these messages as important and noteworthy. According to Rosenshine (1997) there is a connection between the instructor's voice variation and student's achievement. A lecturer can use louder voice pitch when the attention of students is wandering. Rosenshine adds that body language of the lecturer influences student learning. She argues that students remember the lecturer's statements better when they are accompanied by the use of non-verbal language, which means that a lecturer should be able to use the right gestures to enhance student understanding of the subject being consolidated.

The third concept, receipt of information, deals with how the information, meaning and attitudes conveyed by a lecturer may or may not be perceived by the students. Concentration will fluctuate in the process of lecturing; attention is increased if students are engaged in the process and this may be achieved by granting students an opportunity to engage in discussions, by asking them questions, engaging them in problem-solving and even allowing them to ask questions. Lecturing cannot end with the presentation of facts or information; the information must be received by the student. The last basic concept output argues that at the end of the lecture there are learning outcomes that are expected from the student. According to Burkill, Dyer and Stone (2008), any 
instructional strategy should lead to the objectives and interrelated goals for a course of study, therefore students' response or 'output' is a vital aspect in the process of lecturing, and it may occur as an immediate reaction to the lecture or the lecturer. However, much more important are the long-term changes in the student. A lecturer may change students' perceptions of a problem or theory, it may increase students' insight, and it may stimulate the student to read, think, and discuss ideas with one another. Whether these are achieved is largely determined by the students' knowledge, attitudes, and motivation to learn and the lecturer's preparation, lecture structure and presentation.

Lecturers' experiences of lecturing therefore would be understood to include all experiences with students and other stakeholders in the process of knowledge construction. However, the term 'lecturing' in this paper will be used both as a method of instruction as well as the process of teaching and therefore the meaning is contextual. Lecturing is expected to result in learning and as such lecturers have to do whatever it takes to ensure that their efforts lead to learning. Due to the diversity of students and their differences in learning, the lecturer is expected to adopt a lecturing style that suits the students. Students in one class can differ in the ways in which they learn, that then implies that the lecturer in that classroom has to make use of different styles in his or her lecturing in order to reach out to all students. Herein lies the root of most challenges faced by international postgraduate student lecturers, who have come to South Africa from different countries, with different backgrounds, and different orientations on the teaching and learning process.

\section{Research Design and Methodology}

This paper is a qualitative case study of experiences of international postgraduate students lecturing in a university in KwaZulu-Natal. Denzin and Lincoln (2012) posit that qualitative research is a type of research which studies and gathers detailed empirical data from introspection, personal experience, interviews, documents and artefacts which describe in detail problematic situations of phenomena. This definition suggests that qualitative research is a research approach that seeks to locate all information possible about the phenomenon being studied so as to generate new knowledge. Mahoney and Vanderpoel (2015) concur that qualitative research is all about generating different levels of truth or reality from the perspective of as many people as possible in society. This makes qualitative research a type of research that is geared towards investigating phenomena in their natural setting so that the different experiences participants have of such a phenomenon constitutes greater understanding about that phenomenon.

Case study is the most appropriate qualitative research method for this paper because it explores and investigates contemporary real-life phenomenon through detailed contextual analysis of a limited number of events or conditions and their relationships (Zainal, 2007). Cohen et al. (2011) define a case study as an orderly or comprehensive examination of a particular case in its context in order to generate data. Cohen et al. further argue that a case study provides an in-depth examination of an incident or example and analyses, in details the various examples and phases that make up the lifecycle of the unit being explored. In this paper the case was international postgraduate students, and the unit of exploration was the experiences of these students lecturing in the university.

\subsection{Participants}

Six participants were identified as international postgraduate students that also took up lecturing roles during the course of their study. Three participants were pursuing a Master's degree while the other three were at a $\mathrm{PhD}$ level in order to ensure representation. These postgraduate student lecturers chosen as the sample for this research were all lecturers within the same university. They were available at the university on a daily basis and as such, were accessible to the researcher. Participants were therefore chosen on the basis of availability and affordability. The researcher adopted purposeful sampling as a sampling strategy for this research. Chithra and D'Almeida (2014) explain that purposive sampling is always used to generate data from people who are specialised knowledge on a field. They argue that it saves time to just access those who possess the knowledge the researcher needs, rather than randomly sampling a larger population. In this type of sampling, the researcher makes the decision concerning all individuals included in the sample, based on a well thought out criteria, ranging from specific experiences or specialist knowledge to capacity and/or the willingness by such individuals to take part in the study. In this research, the researcher purposefully chose participants who are international postgraduates engaged in lecturing, and as such, possess valuable experiences in lecturing in a foreign country.

\subsection{Research Instrument}

Qualitative research focuses on in-depth data generated using structured or semi-structured interviews, focus group interviews, unstructured questionnaires, document analysis, observation (both participant and non-participant observation), journals, group discussions, pictures, and collages, amongst others (Binh and Tung, 2015). Semi-structured interviews were used as instruments to generate data in this research, and each interview lasted about 60 minutes. Semi-structured interviews uses open-ended questions to help the researcher fine-tune the 
topic being explored, and also allows the researcher to choose to discuss some sub-topics in detail, while briefly discussing others depending on their relevance (Cohen \& Crabtree, 2008). As such, if the participants find it difficult to answer a particular question or can only briefly touch on it, the researcher can ask further questions which will help unearth the required data. The Semi-structured interview questions used by this study centered on the experiences and challenges of international postgraduate student lecturers in South Africa.

\subsection{Data Analysis}

According to Strauss and Corbin (1990), the process of data analysis starts with the classification of themes arising from the generated data. Within this process, the researcher will identify concepts and categories in which experiences observed will be grouped. For this research, based on several qualitative studies, data analysis was inductive and guided by literature. From the interview transcripts, the researcher jotted down ideas about the meaning of the raw data and how it might relate to other issues. This process of reading through the data and interpreting them continued throughout the project. Once the researcher realised that concepts need to be investigated or new relationships explored, the researcher adjusted the data generation. Using the open coding process, data generated were coded and four themes emerged. These themes that emerged followed the same steps as excerpts were derived at through recurrent patterns of meaning, and interpretations by the researcher of the participants' account of their experiences. Theoretical concepts were used in the analysis to make maximum psychological sense of the data. Themes that emerged using this method of data analysis include; cultural shock, work-study balance, technological barrier, academic resources. Each theme will be elaborately discussed below.

\section{Findings and Discussion}

This section explores in detail the above-mentioned themes and make further meaning of them. These themes bring to the limelight the experiences of postgraduate students and how they can be supported to be more efficient.

\subsection{Cultural Shock}

Furnham (2004) defines culture shock as referring to the various emotions one feels when moving to a foreign country. Adding to this, Oberg (1960) defines culture shock as the consequence of, and anxiety resulting from, contact with a new culture and feelings of loss, confusion and impotence which are due to loss of accustomed cultural cues and social rules. The degree of shock experienced by these students differs depending on how prepared they are for the new environment, the cultural knowledge and identity, their expectations, the availability of support systems, the degree of differences between their culture and the new culture, as well as the individual personality traits (Yost \& Lucas, 2002). When international students move to a foreign country, familiar cues are removed and this often results in anxiety for most of them. According to results from Newsome\& Cooper (2016), many international students studying I Britain came a lot of high, and unrealistic expectations. These students upon arrival soon experienced feelings of distress in response to the unfamiliarity of their surroundings.

The international students in this paper indicated a loophole in this area, explaining that one of the challenges they have is unfamiliarity with the society from which their students come from, which presents a challenge for them in presenting activities with which students can relate. They reported that at times they notice that their students are not familiar with the examples they make. One of the participants reported that he once even had an issue that involved a student due to unfamiliarity with South African society. He reported that:

...the issue of background, for example I like to make joke in class to make my student calm but initially I didn't know that South Africa is a country that is sensitive to some jokes, there are some jokes I could share in my class back home and people would not be offended but here it can cause a lot of trouble, like the issue of gender, back home, there is no much tension on the issue of gender and race, but here you have to be careful if you want to make any example..

This scenario becomes almost impossible when the lecturer is coming from a totally different world, still struggling with issues like new culture and language, and thus limiting the international students' abilities to engage with activities prescribed by the curriculum. One of the most common challenges encountered by international students is that of language barriers. Hammer (1996) defines language barrier as the difficulty experienced by students when there is no common language to communicate with one other. International students come from different backgrounds and as such their language of communication differs from South African students. The use of English as a language of instruction in South Africa has been a major problem for international students. According to Madinga, Maziriri and Lose (2016), the English language includes different pronunciation, general meaning of terms by local and international students as well as the meaning of certain words in different contexts. In South Africa, international students come from vast backgrounds, some of which are from French speaking or Portuguese speaking countries and other various indigenous languages. For some of these students, it is their first time communicating in English (Heikinhend \& Shute, 1986). 
Apart from the language issue, there are other issues relating to skin colour, social rules, and even religion. Another participant reported that;

When I started here, there was an example I made about Christians and Muslim and it caused a lot of trouble for me and I didn't know. It was later that one of the senior lecturers corrected me and told me that topic was very sensitive and I should never raise it in class. And one time a student made a joke about my country and everybody laughed and I was offended, I tried to tell coordinator about it. There are some things that I need to understand that this is no longer my country, I had to learn about the culture here.

The findings of this study are consistent with the study by Baier (2005), on the adaptation of international students to the U.S culture. Five themes emerged from the respondents of this study by Baier, and they include language and communication problems, life style and cultural differences, and social support and making friends. Fifteen people explicitly mentioned language and communication problems as their most difficult experience while studying in the United States. The degree of shock experienced by these students differs depending on how prepared they are for the new environment, the cultural knowledge and identity, their expectations, the availability of support systems, the degree of differences between their culture and the new culture, as well as the individual personality traits (Yost \& Lucas, 2002). When international students move to a foreign country, familiar cues are removed and this often results in anxiety for most of them. This degree of stress experienced by these students may not necessarily be the same, for example students coming from the neighbouring countries of South Africa may have a similar culture with South Africa, and therefore would have less struggles in adapting in South Africa than those coming from afar.

\subsection{Study-Work-Life Balance}

According to Abbott (2013, p. 44), "work-life balance is a state where an individual manages real or potential conflicts, between different demands on his/her time and energy, in a way that satisfies his/her needs for well-being and self-fulfillment." The concept of 'study-work-life-balance' emerges in relation to work-life-balance, but takes into cognisance the experiences of students who have to combine activities in their private lives, work obligations, and the demands of their studies. A study by Pookaiyaudom (2015) which explores the effects of work-life balance on some international students at a university in Thailand reveals that, the workload and working hours of the student had a significant impact on their study-work-life-balance. Pookaiyaudom insists that international students who are away from their family and friends, and cannot access their support find it difficult to manage their personal life, study, and work demands. International postgraduate students see lecturing as a way of securing financial resources to sustain their lifestyle. Martinez et al., (2013) posits that doctoral students' departure is majorly linked to financial constraints. One of the participants, speaking about her experience pointed out that;

"the main reason was because of financial constraints. I had no one who was supporting me financially, and so I had to lecture".

This experience was not unique to participant two, as participant four pointed out similar experiences. She stated: I came to South Africa as a research student hoping that I would be able to secure funding, but it turned out the only funding available was for local students. Although my family back home was supporting me financially it was not enough and as such I had to find means to survive while studying, which is when I started looking for a lecturing job.

Financial constraints proved to be a strong rationale for international postgraduate students to lecture. Failing to find funding, they often turn to lecturing as a way of securing finances to meet their needs. Du Plessis and Fourie (2011) argued that international students act as huge sources of income for South African universities, and most of these students find it hard to pay the ever-increasing students fees that international students are expected to pay. The international levy added to the student fees paid by international students often brings additional financial constraints, especially those from other African countries. Most of these students decide to pursue lecturing opportunities whilst in order to support their studies, but this is also sometimes a challenge. First, is the challenge of time. Higher education institutions in South Africa offer a flexible work time for lecturers. Lecturing periods often run from $8 \mathrm{am}$ to $4 \mathrm{pm}$, except in the case of those who run evening programmes. Lecturers are expected to be at work when they have classes to teach. Once they are done with classes they are free to attend to their research work or even leave their offices. Student contact time should not only be limited to delivering lessons but should also include time for guidance and provision of feedback to students.

According to lecturers in this research, allocated time refers to one of the following elements: lecturing time, the time spent on the course, classroom time, time students spend on the subject (engaged time), and dead time. These different measures present various ways of conceiving and using time and not merely time spent in different environments. Time therefore involves various aspects and measures and how a lecturer manages it will determine the effectiveness of teaching and learning.

Morgan and Hansen (2008) argued that some lecturers have issues with time, especially lecturing time, and they find it frustrating that there is little time and that there are a lot of preparations to be done before the starting of a lesson. 
Participants in a study by Martinez et al., (2013) suggest that time is an integral component to school-work-life balance, particularly because as time is allocated to one domain, less time is allocated to another. At least 4 to 5 participants in their study cited time management as their greatest challenge, and balancing it was imperative. This is the case of most postgraduate student lecturers in this study who try to balance their work time, with study time. One participant states that;

I have lectures in the morning as early as 8am and also in the afternoon, my last lesson usually finishes at 3:30pm. I teach 2 groups for 4 periods per day 3 times a week. A lesson takes about 45 minutes but it's usually double period.

To this participant, time is understood as the length of time spent lecturing a particular course and this time varies from course to course.

...in the morning students come to class late because of transport but they participate, but in the afternoon, which is after 1pm, students are tired and cannot concentrate, some will leave early to catch their busses. The best lectures are from 9am to 11pm.

Another participant also added to this by stating that: Mornings are usually the best sessions because the student is still fresh and able to concentrate. However, for 8am we usually have students coming late, there is a lot of disruption as student will be entering late. Students staying at home always complain about transport to get to the campus early and those ...[staying in] student accommodations also come late as the bus will leave them behind and are forced to take the next bus.

The challenge for the participants in this research was that they had students who stay away from the campus and use public transport and university busses; these students leave home or their residences in the morning, and some have to wait until they get home in order to eat, and as such, in the afternoon they want to rush home and are unwilling to stay in afternoon classes and learn. Supporting this view, one participant stated that:

Due to having to travel to school their students arrive late for morning sessions, which means they will miss some parts of the lessons. Also in the afternoon they do not stay for full sessions in class because they need to catch their transport back to where they stay. For this reason I do not in most cases lecture for the entire sessions because students will be [in] a hurry to leave.

These patterns of class attendance affects the student-lecturers' schedule as he tries to fix his lecture sessions at a time suitable for the students, barring other plans.

\subsection{Technological Barrier}

Currently technology plays a key role in teaching and learning, and teachers are encouraged to learn more on using computers to meet these demands, which suggest that the role of a teacher is rapidly changing (Fomunyam, 2014). Teachers are now forced to learn different teaching strategies that involve technology. Some of the participants in this research pointed out that in their home countries they are behind in terms of technology compared to South African universities. One participant said:

One issue was technology, the technologies this university uses, some of them I had never seen them before. I walked in lecture venue for the first time and found a projector, I had never seen it before, I didn't know how to connect it to my laptop. I had to call someone to come and assist and that was not the last time, I would walk in different venues and find different projectors and I constantly had to look for someone to come and help me.

Technology of Education, which is also known as ideological ware (IW) is a teaching resource that cannot be seen or touched (Khoza, 2012), for example learning theories, teaching philosophy, experiences, curriculum knowledge and others (Khoza, 2014). According to Khoza (2012), any person or thing that communicates lecturing becomes a teaching and learning resource. Khoza (2015) opines that Educational Technology (ET) is one of the lecturing resources and consists of Technology in Education (TIE) and Technology of Education (TOE). Technology in Education is divided to hardware (HW) and software (SW) (Khoza, 2012). Hardware refers to any machine or tool that can be used in teaching and learning. HW in the teaching and learning environment includes desktop computers, laptops, cellular phones and others that are used to facilitate teaching and learning (Khoza, 2015). Software is any material that is created for the hardware to display information, for example, PowerPoint slides, transparencies, worksheets and others (Khoza, 2012). Long and Dunne (2014) argue that lecturers need to be encouraged to create their own resources that they consider useful that will fall within the context of the learner in the interest of professional development. Information Communication Technology promotes interactive lessons and offers lecturers a sense of confidence when using a variety of lecturing strategies that best achieve the outcomes of the curriculum (Leenderts et al., 2013).

Another participant also reported the same experience saying;

The first challenge I had teaching in this university was with the technology. From where I come from not as technologically advance[d] as South Africa [is]. As a researcher and as a lecturer I faced challenges in using the technologies that this university uses.

The inability to use the latest technologies is a challenge for both these participants and as such, this means that they cannot fulfil their role of teaching the modern class. Gerschel (2005) argues that as the role of a lecturer is 
evolving so does the need for training to improve their knowledge, skills and confidence.

\subsection{Academic Resources}

A resource is defined by Khoza (2012) as anything that facilitates learning or anyone or anything that communicates learning. Yara (2010) opines that lecturing material such as textbooks, classrooms, laboratories, libraries, stationery and lecturing aids affect learning. Jimenez-Castellanos (2010) states that lecturing resources can either promote or hinder the ability to develop school culture and high-quality instruction. For successful teaching and learning, as well as successful implementation of the curriculum, the availability of sufficient and relevant resources is a necessity (Commonwealth of Learning, 2000).

A research participant reported a challenge with employing continuous assessments in their large classrooms due to the limited resources. She pointed that:

We no longer have the required resources anymore, with the introduction of Moodle, students no longer have course packs, and we can't even do practical work like activities at the end of a unit in language studies. When you teach you have to ask questions and engage the students. If you ask them to open the activities from Moodle from their phones, some will be busy chatting on social media, and some will say that connection is the problem. We have no material to even project in class, in some classes we use we don't even have projectors. Some students complain that they live at home and they do not have laptops, so they have to be on campus to access the material and in most cases they find computers occupied so it becomes difficult for them to access the material. When we had course packs it was easier because at the end of every unit $u$ would give the activities and then do corrections together with them. Now they don't have course packs, students simply look at you and you don't even know whether they understand or not.

For this participant, it was not possible to engage the students in continuous assessment because students do not have access to learning material. Learning material is accessed through Moodle and students are expected to print the material out before coming to the classroom but some student come to class without the study material. Another resource challenge deduced from this participant's response is the conduciveness of the learning environment. Lecturing goes far beyond just a classroom, and includes the university grounds, the library and the immediate neighbourhood of the university (Killen, 2007). Bamford (2008) argues that the main responsibility of higher education institutions is to provide the students with a learning environment that enables the students to develop their knowledge, skills and values; this suggest that the learning environment is important in ensuring that learning actually takes place, and as such, educational institutions should endeavour to provide a learning environment that promotes effective learning.

To facilitate learning, Garet et al. (2001) assert that lecturers should be permitted to try out new teaching strategies in the classroom and obtain feedback about their teaching. However, a participant in this research pointed that they are limited in trying certain teaching strategies in their classrooms, as she explained that:

In most cases the classes are always small[er] than the number of students. You sometimes have situation whereby the student are filled up to a point that you cannot even move around, you have to remain in front of the lecture venue. While you are standing in front some students there at the back are doing their own thing, not listening because the slides that we use in class we are expected to also post on Moodle, as such student do not bother listening because they know that they will get the study material at Moodle. Also, some of the venues have built-in furniture, and it becomes impossible to group the students in smaller groups.

Due to the lack of lecturer-student interaction, it becomes difficult for the lecturer to identify the challenges that the students are facing. Another important element of teaching and learning is feedback; the lecturer should be able to give students regular feedback. It becomes difficult for a lecturer to offer personalised feedback in a large classroom (Rowe, 3011). In the study by Gibbs (1992), students expressed their dissatisfaction with inadequate feedback. Moreover, Garlen, Karlenzig and Tamney (1995) maintain that large classrooms are a source of stress, increasing the workload for lecturers. Lecturers not only deliver lessons but also have some administrative roles, and in large classrooms it becomes stressful for the lecturer to balance all these roles, and as such their ability to teach and their wellbeing are affected. A similar experience was reported by another participant who pointed out that:

I lecture in different venues as allocated for that particular module. Some classes are okay especially the fourth years, there is enough space. However, I have classes that are big to a point that some students will not have desks to sit on and they will compelled to go fetch desk from the next classrooms. It can be horrible in those classes, even if you feel like it's necessary for the students to engage in group work it can be impossible, I would not even be able to coordinate the groups because there are so many students and I practically cannot move around.

A challenge of large class sizes has been reported to exist in higher education (Opoku-Asare, Agbenatoe \& DeGraft-Johnson, 2014). As such, higher education institutions make use of lecture theatres. In these classes you find up to 700 hundred students being taught by one lecturer. This is a huge challenge as a student lecturer in 
this case may be unable to manage such amount of students at once, making it difficult for learning to take place. Another participant in this study complained that;

There is a textbook that we use, I use a laptop, and projector for lectures, and sometimes I use the chalkboards because some of the classes I use do not have projectors. However, this has not been the best year because we usually have course packs for students but this year we had no course pack. Students could only access the study material through Moodle. That has limited me in terms of doing activities because student had to check online for the material and in some someday we did not have internet connection and so I had to cancel class activities. Also, having students read material from their cell phones and laptops is disruptive sometimes I will be standing in front of the lecturing and they will be busy with social media.

The value of any lecturing resource is on its usefulness in promoting learning. The introduction of Moodle (Modular object orientated dynamic learning environment) has been reported to be a great development in teaching and learning, however the reported cases in this research means that the use of Moodle needs to be combined with other materials in order to reach all students and ensure learning takes place. The replacement of course material with Moodle is reported by the above participants to be ineffective due to a number of factors, like access - some student are unable to access study material through Moodle because they have no access to internet at home, on campus computers are limited and also some student lack the necessary computer skills. The above participants have expressed the insufficiency of resources as a problem for teaching and learning.

\section{Conclusions and Recommendation}

This research adopted the use of qualitative case study research methods to explore the experiences of international postgraduate students lecturing in South Africa, with focus on a university in KwaZulu-Natal. International students from different countries were included in the sample so as to maintain generalisation. Findings derived indicate that the experience of these participants are similar, and in most cases the same. Challenges identified include cultural-shock, study-work-life balance, technological barrier, and inadequate academic resources.

Improving their wealth of knowledge by gaining both theoretical and practical knowledge is key to ensuring development for international post graduate students in South Africa. This paper therefore recommends that the university needs to evaluate a number of issues when allocating time for lectures. This research also recommends that international postgraduate lecturing students be enrolled in non-compulsory language classes where they will be taught the basics of the local language so that they will be able to relate with their students. Furthermore, exposure to the belief systems of different groups of the country is necessary. Some of these lecturers reported that it was in their classrooms that they learnt that there are certain statements that are not acceptable to make in some of the South African cultures and they did not know this. It is not enough to just receive new staff and send them to the classroom, but they need to be introduced to the belief system, and prepared for what awaits them in the classroom, in terms of the culture of the students and what is acceptable and not acceptable. The university could host cultural activities where lecturers from different countries can meet together and learn about different cultures, enabling these international lecturers to learn more about the local beliefs.

Also, there is a need for the learning environment to be revisited and enhanced to facilitate learning. Libraries and classrooms which are part of the learning environment should be in a state that promotes effective teaching and learning. These should be big enough to accommodate the number of students and must be equipped with the right resources required for effective learning. Over-crowded classrooms affect both the lecturers and students, and should be strongly discouraged. All learning resources needed to ensure a seamless learning process should be made available, because it is difficult to engage students in class activities due to both limited resources and time constraints. The university has to ensure that these post graduate student lecturers are capacitated to utilise the latest technology in their classrooms. New lecturers should be offered training in the use of technologies used for delivering a lesson before they are sent to classes.

\section{REFERENCES}

[1] Abbot, P. (2013). Work/Life Balance. Accountancy SA, 44-45. Retrieved From: http://www.accountancysa.org.za

[2] Amua-Sekyi, E. T. (2010). Teaching in universities in Ghana: The tensions and dilemmas.

[3] Atkins, M., Brown, A., \& Brown, G. (2002). Effective teaching in higher education. London: Routledge.

[4] Baier, S.T. (2005). International Students: Culture shock and Adaptation to the U.S Culture. Master's Theses and Doctoral Dissertations. 523.

[5] Bamford, J. K. (2008). Improving international students' experience of studying in the UK. The Economics Network.

[6] Binh, N. T., \& Tung, K. T. (2015). A Novel Test Data Generation Approach Based Upon Mutation Testing by Using Artificial Immune System for Simulink Models. In Knowledge and Systems Engineering (pp. 169-181). Berlin: Springer International Publishing. 
[7] Burkill, S., Dyer, S. R., \& Stone, M. (2008). Lecturing in higher education in further education settings. Journal of Further and Higher Education, 32(4), 321-331.

[8] Chithra, P. N., \& D'Almeida, S. (2014). Effectiveness of Hand and Foot Massage on Pain among Women who have Undergone Abdominal Hysterectomy in Selected Hospitals at Mangalore. Asian Journal of Nursing Education and Research, 4(3), 337-341.

[9] Cohen, D. \& Crabtree, B. (2008). Qualitative Research Guidelines Project. Robert Wood Johnson Foundation Press. http://www.qualres.org/HomeSemi-3629.html

[10] Cohen, L., Manion, L. and Morrison, K. (2011). Research Methods in Education. New York: Routledge.

[11] Cotton, D. R. E., Warren, M. F., Maiboroda, O., \& Bailey, I. (2007). Sustainable development, higher education and pedagogy: a study of lecturers' beliefs and attitudes. Environmental Education Research, 13(5), 579-597.

[12] Denzin, N. K., \& Lincoln Y. S. (Eds.), (2012). The Landscape of Qualitative Research (4th Ed.). Thousand Oaks, CA: Sage Publications.

[13] DeWinstanley, P. A., \& Bjork, R. A. (2002). Successful lecturing: Presenting information in ways that engage effective processing. New directions for teaching and learning, 2002(89), 19-31.

[14] Di Pietro, G. (2015). Do study abroad programs enhance the employability of graduates?. Education Finance and policy, 10(2), 223-243.

[15] Duplass J. (2006). Middle and High School Teaching: Methods, Standards, and Best Practices. Boston: Houghton Mifflin Company. p. 204.

[16] Du Plessis, E., \& Fourie, J. (2011). Higher education exports in South Africa: A case study of Stellenbosch University. South African Journal of Higher Education, 25(3), 460-475.

[17] Fomunyam, K. G. (2014). Curriculum theorizing and individualism: An exploration of the curriculum's relation to the social, personal and political dimensions of schooling. Mevlana International Journal of Education (MIJE), 4(2), 122-131.

[18] Furnham, A. (2004). Foreign students: Education and culture shock. The Psychologist, 17(1), 16-19.

[19] Gallen, R., Kallenzig, E. \& Tamney, A. (1995). Teachers' work intensification. Canadian Review of Sociology, 21 (2), 312-319

[20] Garet, M., Porter, A., Desimone, L., Birman, B., Yoon, K. (2001). What makes professional development effective? Results from a national sample of teachers. American Educational Research Journal, 38(4), 915-945.

[21] Gibbs, G. (1992) Assessing More Students, Oxford: Oxford Centre for Staff Development.

[22] ICEF Monitor. (2017). South Africa Remains an Important Regional Hub for Education. Published March 13, 201. Retrieved from: https://www.monitor.icef.com

[23] Jimenez-Castellanos, O. (2010). Relationship between educational resources and school achievement: A mixed method intra-district analysis. The Urban Review, 42(4),
351-371.

[24] Kember, D. (1997). A reconceptualisation of the research into university academics' conceptions of teaching. Learning and instruction, 7(3), 255-275.

[25] Khoza, S. B. (2012). Who helps an online facilitator to learn with students in a day? Mevlana International Journal of Education, 2(2), 75-84. Available online at http://mije.mevlana.edu.tr/.

[26] Khoza, S. B. (2013). Learning Outcomes as understood by 'Publishing Research' facilitators at a South African university. Mevlana International Journal of Education, 3(2), 1-11. Available online at http://mije.mevlana.edu.tr/

[27] Khoza, S. B. (2014). Using curricular spider web to explore a research facilitator's and students' experiences. South African Journal of Higher Education, 28(3), 1-14.

[28] Khoza, S. B. (2015). Student teachers' reflections on their practices of the curriculum and assessment policy statement. South African Journal of Higher Education, 29(4), 179-197.

[29] Killen, R. (2007). Teaching strategies for outcomes-based education. Juta and Company Ltd.

[30] King, R., \& Ruiz - Gelices, E. (2003). International student migration and the European 'year abroad': effects on European identity and subsequent migration behaviour. Population, Space and Place, 9(3), 229-252.

[31] Knight, J. K., \& Wood, W. B. (2005). Teaching more by lecturing less. Cell biolog education, 4(4), 298-310.

[32] Mahoney, J., \& Vanderpoel, R. S. (2015). Set Diagrams and Qualitative Research. Comparative Political Studies, 48(1), 65-100.

[33] Martinez, E., Ordu, C., Sala, M.R., \& Mcfarlane, A. (2013). Striving to Obtain a School-Work-Life Balance; The Full-Time Doctoral Student. International Journal of Doctoral Studies, Volume 8.

[34] Morgan, P. J., \& Hansen, V. (2008). Classroom teachers' perceptions of the impact of barriers to teaching physical education on the quality of physical education programs. Research quarterly for exercise and sport, 79(4), 506-516.

[35] Mutala, S.M. (2011). Challenges of Postgraduate Research: Case of Developing Countries. South African Journal of Libraries and Information Science, 77(2). DOI:10.7553/77-2-60.

[36] Newsome, L.K., \& Cooper, P. (2016). International Students' Cultural and Social Experiences in a British University: "Such a Hard life it is Here". Joural of International Students, 6(1); 195-215.

[37] Nilsson, P. A., \& Ripmeester, N. (2016). International student expectations: Career opportunities and employability. Journal of International Students, 6(2), 614.

[38] Oberg, K. (1960). Cultural shock: Adjustment to new cultural environments. Practical anthropology, 7(4), 177-182.

[39] OECD. (2008). Education at a Glance 2007: OECD Indicators. Paris, France.

[40] Opoku-Asare, N. A., Agbenatoe, W. G., \& DeGraft-Johnson, 
K. G. (2014). Instructional strategies, institutional support and student achievement in general knowledge in art: Implications for visual arts education in Ghana.

[41] Pookaiyaudom, G. (2015). Assessing Different Towards the Importance of a Work Life Balance: A Comparable Study Between Thai and International Programme Students. Procedia- Social and Behavioural Sciences, 174(2015), 267-274

[42] Rainie, L., \& Anderson, J. (2017). The future of jobs and jobs training. PEW Research Center Retrieved from http://www.Pewinternet.org/2017/05/03/the-future-of-jobsand-jobs-training.

[43] Rosenshine, B. (1997). The case for explicit, teacher-led, cognitive strategy instruction. MF Graves (Chair), What sort of comprehension strategy instruction should schools provide.

[44] Rowe, A. (2011). The personal dimension in teaching: Why students value feedback. International Journal of Management, 25(4): 343-- 344. Rudduck, J. (2007). Student voice, student engagement and school reform. In International handbook of student experience in elementary and secondary school, eds. D. Thiessen and A. Cook-Sather, 587-610. Dordrecht, The Netherlands: Springer.
[45] Schulmann, P. (2017). African Student Mobility: Regional Trends and Recommendations for U.S. HEIS. World Education News, Reviews (WENR). Retrieved from: https://www.wenr.wes.org.

[46] Strauss, A., \& Corbin, J. (1998). Basics of qualitative research: Techniques and procedures for developing grounded theory (2nd ed.). Thousand Oaks, CA: Sage Publications.

[47] UNESCO Institute for Statistics (UIS). (2009). Global Education Digest 2009: Comparing Education Statistics Across the World. Montreal: UIS.

[48] Yost, A. D., \&, Lucas, M. S. (2002). Adjustment issues affecting employment for immigrants from the former Soviet Union. Journal of Employment Counseling, 39(4), 153-170.

[49] Yara, P. O., \& Otieno, K. O. (2010). Teaching/learning resources and academic performance in mathematics in secondary schools in Bondo District of Kenya. Asian Social Science, 6(12), 126.

[50] Young, M. R. (2002). Experiential learning= hands-on+ minds-on. Marketing Education Review, 12(1), 43-51.

[51] Zainal, Z. (2007). Case study as a research method. Jurnal Kemanusiaan, 5(1). 